\title{
Analysis and Research on the Aggregation of Producer Services in China
}

\author{
Dong Liang, Liu Lanjuan \\ Department of Information Management and Engineering, Shanghai University of Finance and Economics, Shanghai, China \\ dongliang@fudan.edu.cn,1ljuan@mail.shufe.edu.cn
}

\begin{abstract}
Producer Services has played a crucial role for the city's economic development, industrial structure optimization and transformation. In our paper we used the 31 provinces (city) Chinese employment data to computing the aggregation of Producer Services by Location Entropy, Spatial Gini coefficient and Spatial concentration index, explored the status of aggregation of Producer Services. We found that the Producer Services were on space diffusion trend while they are in the aggregation in the large city. Our paper pointed out that the city construction has influence on the Producer Service. Especially the development of the smart city has "squeezing" effect on the Producer Service, the one hand to promote the aggregation of Advanced Producer Services, on the other hand, to push the Low-end Producer Services diffusion to the surrounding city.

Index Terms - Producer Services, Aggregation, Diffusion, Smart City
\end{abstract}

\section{Introduction}

After the thirty years of reform and opening up, the economy of China has developed rapidly. In the 12th five-year plan Period, by the third industrial revolution, the application of a new generation of information technology is expanding, the development of the city gradually towards informatization and services. The Producer Services has played a crucial role for the city's economic development, industrial structure optimization and transformation. In this background, we discussed the aggregation of Producer Services in China, especially to explore the potential relationship between the large city and the aggregation of Pro-ducer Services has very important prac-tical significance.

\section{Research Review: Producer Services Aggregation}

The research of Producer Services abroad started early. In early stage, many scholars believed that the progress of Producer Services were on diffusion trend. Gillespie and Green (1987) proposed the opinion that the progress of Producer Services were on inverse urbanization, and Scott (1988) put forward that the progress of Producer Services were on more scattered trend, because the enterprises can share the results of other enterprises in wider region network for the development the information technology. However, many research showed that Producer Services were in uneven development in space, that the progress were on the quite diffusion trend while they are gathering. Coe's report indicated that the Producer Services are urban aggregation. Selya's research showed that the Producer Services were on space diffusion trend while they are in the aggregation. The service can get rid of the space by the development of information technology, and the Producer Services can provide the service for the enterprise wherever it is. Most of the research in China focused on figuring out the aggregation level.Hu xia calculated the aggregation level of Producer Services and their internal industry in China by entropy. Luo Fang and Yang Liangliang (2013) figured out the aggregation effect of Producer Services in Yangtze River Delta. At present the research literatures which focused on the analyzing about the aggregation level of Producer Services in China based on the coexistence of diffusion and aggregation, are not much. This paper discuss the aggregation of Producer Services, based on the employment data in 31 provinces of China Statistical Yearbook (2004 2012), using Location Entropy, Spatial Gini coefficient and Spatial concentration index. And the paper makes preliminary study on the aggregation and diffusion effect of Producer Services in metropolis.

\section{Computing the Aggregation of Producer Services in China}

A. Location Entropy

According to the location entropy calculation formula:

$$
L Q=\frac{X_{i j} / \sum_{j} X_{i j}}{\sum_{\mathrm{i}} X_{i j} / \sum_{i} \sum_{j} X_{i j}}
$$

$\mathrm{Xij}$ represents the employment in $\mathrm{j}$ industry of area $\mathrm{i}$. The six industries' location entropy of Producer Services from 2003 to 2011 can be calculated, detailed in the following Tables: 
TABLE 1 Location entropy of Producer Services from 2003 to 2007

\begin{tabular}{|c|c|c|c|c|c|c|c|}
\hline Industry & No. & Year & 2003 & 2004 & 2005 & 2006 & 2007 \\
\hline \multirow{5}{*}{ Transport, Storage and Post } & 1 & Shanghai & 1.8 & 1.83 & 1.84 & 1.86 & 1.75 \\
\hline & 2 & Beijing & 1.12 & 1.24 & 1.38 & 1.63 & 1.66 \\
\hline & 3 & Qinghai & 1.17 & 1.48 & 1.51 & 1.5 & 1.45 \\
\hline & 4 & Liaoning & 1.18 & 1.19 & 1.25 & 1.32 & 1.35 \\
\hline & 5 & Jinlin & 1.51 & 1.51 & 1.28 & 1.25 & 1.19 \\
\hline \multirow{5}{*}{$\begin{array}{l}\text { Information Transmission, } \\
\text { Computer Service and Software }\end{array}$} & 1 & Beijing & 3.61 & 3.49 & 3.63 & 3.88 & 4.72 \\
\hline & 2 & Qinghai & 1.72 & 1.65 & 1.59 & 1.52 & 1.35 \\
\hline & 3 & Xizang & 1.39 & 1.32 & 1.71 & 1.58 & 1.41 \\
\hline & 4 & Guangdong & 1.41 & 1.41 & 1.4 & 1.35 & 1.29 \\
\hline & 5 & Shanghai & 1.12 & 1.12 & 1.23 & 1.22 & 1.25 \\
\hline \multirow{5}{*}{ Financial Intermediation } & 1 & Shanghai & 1.54 & 1.53 & 1.88 & 2.08 & 2.07 \\
\hline & 2 & Xizang & 1.52 & 1.53 & 1.35 & 1.31 & 1.24 \\
\hline & 3 & Ningxia & 1.11 & 1.13 & 1.15 & 1.31 & 1.24 \\
\hline & 4 & Hebei & 1.11 & 1.09 & 1.14 & 1.18 & 1.2 \\
\hline & 5 & Jinlin & 1.09 & 1.1 & 1.21 & 1.15 & 1.15 \\
\hline \multirow{5}{*}{ Leasing and Business Services } & 1 & Beijing & 4.78 & 5.19 & 5.15 & 5.14 & 5 \\
\hline & 2 & Shanghai & 2.31 & 2.34 & 2.29 & 2.41 & 2.26 \\
\hline & 3 & Tianjin & 1.29 & 1.32 & 1.45 & 1.51 & 1.54 \\
\hline & 4 & Zhejiang & 1.63 & 1.45 & 1.47 & 1.51 & 1.32 \\
\hline & 5 & Guangdong & 1.25 & 1.22 & 1.42 & 1.4 & 1.35 \\
\hline \multirow{5}{*}{$\begin{array}{c}\text { Scientific Research, Technical } \\
\text { Services, and Geological } \\
\text { Prospecting }\end{array}$} & 1 & Beijing & 3.46 & 2.8 & 2.96 & 3.11 & 3.07 \\
\hline & 2 & Shanghai & 1.66 & 1.91 & 2.25 & 2.44 & 2.43 \\
\hline & 3 & Qinghai & 2.1 & 2.39 & 2.25 & 2.22 & 1.86 \\
\hline & 4 & Shanxi & 1.85 & 1.89 & 1.93 & 1.93 & 1.84 \\
\hline & 5 & Xizang & 1.75 & 1.76 & 1.56 & 1.49 & 1.41 \\
\hline \multirow{5}{*}{ Education } & 1 & Guangxi & 1.48 & 1.45 & 1.45 & 1.49 & 1.49 \\
\hline & 2 & Guizhou & 1.36 & 1.36 & 1.37 & 1.41 & 1.4 \\
\hline & 3 & Xizang & 1.29 & 1.33 & 1.34 & 1.39 & 1.47 \\
\hline & 4 & Yunnan & 1.37 & 1.42 & 1.46 & 1.47 & 1.31 \\
\hline & 5 & Hebei & 1.24 & 1.27 & 1.29 & 1.3 & 1.31 \\
\hline
\end{tabular}

TABLE 2 Location entropy of Producer Services from 2008 to 2011

\begin{tabular}{|c|c|c|c|c|c|c|c|}
\hline Industry & No. & Year & 2008 & 2009 & 2010 & 2011 & Avg \\
\hline \multirow{5}{*}{ Transport, Storage and Post } & 1 & Shanghai & 1.72 & 1.72 & 1.74 & 1.79 & 1.78 \\
\hline & 2 & Beijing & 1.65 & 1.68 & 1.71 & 1.82 & 1.54 \\
\hline & 3 & Qinghai & 1.37 & 1.34 & 1.34 & 1.22 & 1.38 \\
\hline & 4 & Liaoning & 1.33 & 1.28 & 1.26 & 1.23 & 1.27 \\
\hline & 5 & Jinlin & 1.19 & 1.18 & 1.15 & 1.12 & 1.26 \\
\hline \multirow{5}{*}{$\begin{array}{l}\text { Information Transmission, } \\
\text { Computer Service and Software }\end{array}$} & 1 & Beijing & 4.96 & 4.61 & 4.91 & 4.85 & 4.3 \\
\hline & 2 & Qinghai & 1.25 & 1.1 & 1.02 & 1.01 & 1.36 \\
\hline & 3 & Xizang & 1.32 & 1.18 & 1.11 & 0.58 & 1.29 \\
\hline & 4 & Guangdong & 1.26 & 1.15 & 1.13 & 1.08 & 1.28 \\
\hline & 5 & Shanghai & 1.28 & 1.4 & 1.36 & 1.12 & 1.23 \\
\hline \multirow{5}{*}{ Financial Intermediation } & 1 & Shanghai & 2.02 & 2.08 & 2.19 & 1.59 & 1.89 \\
\hline & 2 & Xizang & 1.36 & 1.25 & 1.34 & 1.1 & 1.33 \\
\hline & 3 & Ningxia & 1.23 & 1.25 & 1.21 & 1.31 & 1.22 \\
\hline & 4 & Hebei & 1.19 & 1.22 & 1.21 & 1.22 & 1.17 \\
\hline & 5 & Jinlin & 1.14 & 1.15 & 1.15 & 1.08 & 1.13 \\
\hline \multirow{5}{*}{ Leasing and Business Services } & 1 & Beijing & 4.82 & 5.02 & 4.93 & 4.3 & 4.92 \\
\hline & 2 & Shanghai & 1.98 & 1.84 & 1.92 & 1.86 & 2.13 \\
\hline & 3 & Tianjin & 1.54 & 1.7 & 1.53 & 1.2 & 1.45 \\
\hline & 4 & Zhejiang & 1.29 & 1.32 & 1.29 & 1.4 & 1.41 \\
\hline & 5 & Guangdong & 1.25 & 1.22 & 1.17 & 1.29 & 1.29 \\
\hline \multirow{5}{*}{$\begin{array}{c}\text { Scientific Research, Technical } \\
\text { Services, and Geological } \\
\text { Prospecting }\end{array}$} & 1 & Beijing & 3.23 & 3.17 & 3.05 & 3.56 & 3.16 \\
\hline & 2 & Shanghai & 2.61 & 2.9 & 3.09 & 1.2 & 2.28 \\
\hline & 3 & Qinghai & 1.83 & 1.94 & 1.96 & 2.15 & 2.08 \\
\hline & 4 & Shanxi & 1.6 & 1.7 & 1.6 & 1.77 & 1.79 \\
\hline & 5 & Xizang & 1.32 & 1.46 & 1.36 & 1.45 & 1.51 \\
\hline \multirow{5}{*}{ Education } & 1 & Guangxi & 1.51 & 1.5 & 1.49 & 1.57 & 1.49 \\
\hline & 2 & Guizhou & 1.52 & 1.53 & 1.55 & 1.57 & 1.45 \\
\hline & 3 & Xizang & 1.49 & 1.57 & 1.54 & 1.64 & 1.45 \\
\hline & 4 & Yunnan & 1.33 & 1.33 & 1.33 & 1.35 & 1.38 \\
\hline & 5 & Hebei & 1.34 & 1.36 & 1.4 & 1.42 & 1.33 \\
\hline
\end{tabular}




\section{B. Spatial Gini coefficient}

According to the calculation formula of Space Gini Coefficient:

$$
\mathrm{G}=\sum_{\mathrm{i}}\left(\mathrm{S}_{\mathrm{i}}-\mathrm{X}_{\mathrm{i}}\right)^{2}
$$

$\mathrm{Si}$ represents the employment of the industry in the area proportion of the total employment of the industry in the country, and $\mathrm{X}$ represents the employment of the area the proportion of the total employment in the country. The industry Spatial Gini Coefficient of six industries in Producer Services from 2003 to 2011 can be calculated, detailed in the following tables:

TABLE 3 Spatial Gini coefficient of Producer Services from 2003 to 2006

\begin{tabular}{|c|c|c|c|c|}
\hline Industry / Year & 2003 & 2004 & 2005 & 2006 \\
\hline Transport, Storage and Post & 0.0018 & 0.0019 & 0.0024 & 0.0030 \\
\hline Information Transmission, Computer Service and Software & 0.0147 & 0.0143 & 0.0157 & 0.0174 \\
\hline Financial Intermediation & 0.0012 & 0.0009 & 0.0012 & 0.0014 \\
\hline Leasing and Business Services & 0.0310 & 0.0371 & 0.0361 & 0.0358 \\
\hline Scientific Research, Technical Services, and Geological Prospecting & 0.0151 & 0.0106 & 0.0121 & 0.0133 \\
\hline Education & 0.0017 & 0.0019 & 0.0021 & 0.0023 \\
\hline
\end{tabular}

TABLE 4 Spatial Gini coefficient of Producer Services from 2007 to 2011

\begin{tabular}{|c|c|c|c|c|c|}
\hline Industry / Year & 2007 & 2008 & 2009 & 2010 & 2011 \\
\hline Transport, Storage and Post & 0.0033 & 0.0035 & 0.0037 & 0.0035 & 0.0043 \\
\hline Information Transmission, Computer Service and Software & 0.0287 & 0.0353 & 0.0338 & 0.0398 & 0.0372 \\
\hline Financial Intermediation & 0.0015 & 0.0014 & 0.0015 & 0.0018 & 0.0014 \\
\hline Leasing and Business Services & 0.0349 & 0.0343 & 0.0425 & 0.0417 & 0.0319 \\
\hline Scientific Research, Technical Services, and Geological Prospecting & 0.0135 & 0.0161 & 0.0180 & 0.0170 & 0.0191 \\
\hline Education & 0.0024 & 0.0027 & 0.0030 & 0.0032 & 0.0034 \\
\hline
\end{tabular}

TABLE 5 Spatial Gini coefficient of Producer Services from 2003 to 2007 in Shanghai and Beijing

\begin{tabular}{|c|c|c|c|c|c|c|}
\hline Industry / Year & & 2003 & 2004 & 2005 & 2006 & 2007 \\
\hline \multirow{2}{*}{ Transport, Storage and Post } & Beijing & - & 0.0001 & 0.0002 & 0.0007 & 0.0008 \\
\hline & Shanghai & 0.0005 & 0.0004 & 0.0004 & 0.0004 & 0.0004 \\
\hline \multirow{2}{*}{$\begin{array}{c}\text { Information Transmission, Computer Service and } \\
\text { Software }\end{array}$} & Beijing & 0.0118 & 0.0111 & 0.0118 & 0.0137 & 0.0243 \\
\hline & Shanghai & - & - & - & - & - \\
\hline \multirow{2}{*}{ Financial Intermediation } & Beijing & 0.0002 & - & - & - & - \\
\hline & Shanghai & 0.0002 & 0.0002 & 0.0005 & 0.0007 & 0.0008 \\
\hline \multirow{2}{*}{ Leasing and Business Services } & Beijing & 0.0247 & 0.0312 & 0.0294 & 0.0283 & 0.0281 \\
\hline & Shanghai & 0.0012 & 0.0011 & 0.001 & 0.0011 & 0.001 \\
\hline \multirow{2}{*}{$\begin{array}{l}\text { Scientific Research, Technical Services, and } \\
\text { Geological Prospecting }\end{array}$} & Beijing & 0.0105 & 0.0057 & 0.0065 & 0.0073 & 0.0075 \\
\hline & Shanghai & 0.0003 & 0.0005 & 0.0009 & 0.0012 & 0.0013 \\
\hline \multirow{2}{*}{ Education } & Beijing & 0.0004 & 0.0004 & 0.0003 & 0.0003 & 0.0004 \\
\hline & Shanghai & 0.0001 & 0.0001 & 0.0001 & 0.0001 & 0.0001 \\
\hline
\end{tabular}

TABLE 6 Spatial Gini coefficient of Producer Services from 2008 to 2011 in Shanghai and Beijing

\begin{tabular}{|c|c|c|c|c|c|}
\hline Industry / Year & & 2008 & 2009 & 2010 & 2011 \\
\hline \multirow{2}{*}{ Transport, Storage and Post } & Beijing & 0.0008 & 0.001 & 0.0012 & 0.0015 \\
\hline & Shanghai & 0.0004 & 0.0004 & 0.0004 & 0.0007 \\
\hline \multirow{2}{*}{ Information Transmission, Computer Service and Software } & Beijing & 0.0306 & 0.0293 & 0.0351 & 0.0335 \\
\hline & Shanghai & 0.0001 & 0.0001 & 0.0001 & - \\
\hline \multirow{2}{*}{ Financial Intermediation } & Beijing & - & - & 0.0001 & 0.0003 \\
\hline & Shanghai & 0.0007 & 0.0008 & 0.001 & 0.0004 \\
\hline \multirow{2}{*}{ Leasing and Business Services } & Beijing & 0.0285 & 0.0362 & 0.0355 & 0.0247 \\
\hline & Shanghai & 0.0007 & 0.0005 & 0.0006 & 0.0009 \\
\hline \multirow{2}{*}{$\begin{array}{c}\text { Scientific Research, Technical Services, and Geological } \\
\text { Prospecting }\end{array}$} & Beijing & 0.0097 & 0.0105 & 0.0097 & 0.0149 \\
\hline & Shanghai & 0.0018 & 0.0025 & 0.0029 & - \\
\hline \multirow{2}{*}{ Education } & Beijing & 0.0004 & 0.0005 & 0.0006 & 0.0005 \\
\hline & Shanghai & 0.0001 & 0.0001 & 0.0001 & 0.0003 \\
\hline
\end{tabular}




\section{Spatial Concentration Index}

According to the calculation formula of spatial concentration index:

$$
\mathrm{EG}=\frac{\mathrm{G}-\left(1-\sum_{\mathrm{i}} \mathrm{X}_{\mathrm{i}}^{2}\right) \mathrm{H}}{\left(1-\sum_{\mathrm{i}} \mathrm{X}_{\mathrm{i}}^{2}\right)(1-\mathrm{H})}
$$

EG represents the total number of employment in area $i$ proportion of the total number of employment in the country, and G represents the Spatial Gini coefficient, and H represents for the Herfindahl index. The spatial concentration index of six industries in Producer Services from 2003 to 2011 can be calculated, detailed in the following tables:

TABLE 7 Spatial concentration index of Producer Services from 2003 to 2007

\begin{tabular}{|c|c|c|c|c|c|}
\hline E-G & 2003 & 2004 & 2005 & 2006 & 2007 \\
\hline Transport, Storage and Post & 0.0019 & 0.0020 & 0.0025 & 0.0031 & 0.0035 \\
\hline $\begin{array}{c}\text { Information Transmission, } \\
\text { Computer Service and } \\
\text { Software }\end{array}$ & 0.0154 & 0.0150 & 0.0164 & 0.0182 & 0.0300 \\
\hline Financial Intermediation & 0.0013 & 0.0009 & 0.0013 & 0.0015 & 0.0016 \\
\hline $\begin{array}{c}\text { Leasing and Business } \\
\text { Services }\end{array}$ & 0.0323 & 0.0388 & 0.0377 & 0.0374 & 0.0365 \\
\hline $\begin{array}{c}\text { Scientific Research, } \\
\text { Technical Services, and } \\
\text { Geological Prospecting }\end{array}$ & 0.0158 & 0.0111 & 0.0127 & 0.0139 & 0.0141 \\
\hline Education & 0.0017 & 0.0020 & 0.0022 & 0.0024 & 0.0026 \\
\hline
\end{tabular}

TABLE 8 Spatial concentration index of Producer Services from 2008 to 2011

\begin{tabular}{|c|c|c|c|c|}
\hline E-G & 2008 & 2009 & 2010 & 2011 \\
\hline Transport, Storage and Post & 0.0037 & 0.0038 & 0.0037 & 0.0045 \\
\hline $\begin{array}{c}\text { Information Transmission, Computer } \\
\text { Service and Software }\end{array}$ & 0.0370 & 0.0354 & 0.0417 & 0.0389 \\
\hline Financial Intermediation & 0.0015 & 0.0016 & 0.0019 & 0.0015 \\
\hline Leasing and Business Services & 0.0359 & 0.0445 & 0.0437 & 0.0334 \\
\hline $\begin{array}{c}\text { Scientific Research, Technical } \\
\text { Services, and Geological Prospecting }\end{array}$ & 0.0168 & 0.0188 & 0.0178 & 0.0200 \\
\hline Education & 0.0028 & 0.0031 & 0.0034 & 0.0036 \\
\hline
\end{tabular}

\section{Conclusions}

Through the previous data, we can clearly find that Producer Services is similar with the manufacturing industry which is born from the manufacturing industry, and both of them have the characteristic of the aggregation economy. In the analysis of data from 2003 to 2011, the data of 3 indexes show that 6 industries of Producer Services in China are on the trend of spatial concentration in some extent, and the trend of Information Transmission, Computer Service and Software,
Leasing and Business Services are obvious, especially. At the same time, the aggregation of high caliber talent resource provide well intellectual support for the development of Producer Services, and the Producer Services are more inclined to develop in urban. With the background of economic globalization and informatization, the phenomenon that the Producer Services gather in urban is more and more obviously, especially phenomenon that the Producer Services gather in metropolis. From nearly 10 years data from 2003 to 2011, some kinds of index in Beijing and Shanghai show the high aggregation.

However, with the development of information technology, Producer Services can be separated from the bondage of spatial location, and it is easy to provide various services to producers, that is to say the information technology promote Producer Services gathered at the same time also makes the separability of Producer Services. In our study of China's 31 provinces, we also find the phenomenon from the time-series data, that not all the Producer Services are on increase trend of gathered. For example, the Leasing and Business Services and Transport, Storage and Post in China show the trend of dispersion to some extent.

Visibly, the trend of China's Producer Services in the metropolis gathering and diffusion is obvious, so further research on the relationship between the wisdom city construction and Producer Services can be made in the future, and it can help the government make some superior Producer Services development well in metropolis, based on the valid adjustment between the guidance and investment of the smart city, with the restriction of limited resources. Therefore, some labor-intensive junior Producer Services develop in the surrounding towns radially. And the population will move to the surrounding town, which benefits the development of urbanization.

\section{References}

[1] Xue Huacheng. Management Information System: Tsinghua University Press, 2012

[2] Beyers WB. Producer Services. Progress in Human Geography , 1993, 17 (2) : 221 231

[3] HENKELJ. Selective Revealing in Open Innovation Processes: The Case of Embedded Linux. Research Policy,2006,35(7): 953-969

[4] Luo Fang, Yang Liangliang. Determinants of producer service agglomeration in Yangtze River delta urban agglomerations: based on the panel data in industrial level. Science-Technology and Management, 2013, 15(5): 54-59

[5] Ding Jingqiu, Zhao Gongmin. On Influence Factors of Central Region of China Producer Service Agglomeration - Based on Empirical Study of Panel Data. Science and Technology Management Research, 2013, 33(10): 166-170

[6] Howells, Green. Location, Technology and Industrial Organization in UK Services. Progress in Planning, 1986, (2). 